\title{
SYSTEMATIC REVIEW ON THE RELEVANCY OF PARACETAMOL AND BREASTFEEDING POST INFANTS VACCINATION
}

\author{
Nurain Suleiman \\ Johor Pharmaceutical Services Division, Ministry of Health of Malaysia \\ Kulliyyah of Pharmacy, International Islamic University Malaysia \\ Siti Hadijah Shamsuddin \\ Kulliyyah of Pharmacy, International Islamic University Malaysia \\ Razman Mohd Rus, Shamsul Drahman \\ Kulliyyah of Medicine, International Islamic University Malaysia
}

Background: Paracetamol may be use as antipyretic agent for the treatment of fever, as well as an analgesic in the treatment of mild to moderate pain on post vaccination in infants. The use of Paracetamol during fever may be or may not be recommended since it may alter natural human body immune response although it may reduce pain.

Objectives: This study described the relevancy of Paracetamol use post infants vaccination based on data collection systematic review analyses. This study aims to describe the effectiveness of breastfeeding in reducing pain and Paracetamol in reducing fever and pain post infants vaccination.

Data Sources and Study Selection: Electronic literature search by hand searching six (6) databases which include Ovid LWW Total Access Collection and Medline, CINAHL (Cumulative Index to Nursing and Alled Health Literature) Plus with Fulltext, Science Direct, Proquest Dissertations and Theses, Proquest Education Journal and Proquest Health and Medical Complete. Additionally, manual reference checks of all articles on Paracetamol and breastfeeding post infants vaccination published in English Language between 1978 and 2017. Two level of screening were used on 9614 citations which include screening of abstracts and titles followed by full text screening.

Data Synthesis: Data synthesis were tabulated into study characteristics, quality and effects. Authors of trials were not contacted for further details or provision of original data if the published report contained insufficient information. The study findings, as reported by the authors, were included in this review. The data in this research cannot be pool due to not enough data regarding odd ratio or relative risk as well as confidence interval in each study.

Results: Systematic review of breastfeeding included three (3) studies from 9614 of database searching. The reviews of all these three (3) studies found significant benefit from breastfed in pain score and duration of crying as well as behavioral changes. None study stated the unbeneficial of breastfeeding before, during and after immunization. Meanwhile, systematic review of Paracetamol effectiveness included four (4) studies from 1177 of database searching. The reviews of two (2) studies found significant benefit from prophylaxis Paracetamol in fever and only one (1) study found significant benefit from prophylaxis Paracetamol in fussiness. On the other hand, there was one (1) study found not signifiant benefit from prophylaxis Paracetamol in fever. Other than that, there were two (2) studies evaluate the safety of prophylactic Paracetamol which revealed different outcomes, in which study by Prymula et. al. in 2009 found that antibody responses to several antigens were reduced significantly, and the other study by Uhari et. al. in 1988 found that antibody titres to DTP bacteria of placebo and PCM not differ significantly. Thus, Paracetamol seems to be not relevant post infants vaccination and breastfeeding was found to be beneficial post infants vaccination.

Conclusions: The relevancy of giving Paracetamol post all types of vaccination may be questionable since the safety issue of this intervention may be arised. Breastfeeding before, 
during and after immunization are recommended for pain reduction as it was proved effectively. Finally, in deciding Paracetamol to be of rational use following infants immunization, it may need for further research which include in depth quantitative and qualitative studies to identify specific problem and causes regarding this issue.

Keywords: Paracetamol, breastfeeding, post, childhood, prophylactic, immunization, vaccination

\section{INTRODUCTION}

Paracetamol may be use as antipyretic agent for the treatment of fever, as well as an analgesic in the treatment of mild to moderate pain on post vaccination in child (Drug Information Handbook, 2006). Current recommendations of different guidelines (American Academy of Pediatrics in 2003 and the Advisory Committee on Immunization Practices in 2002 as well as College of Paediatrics, Academy of Medicine of Malaysia in 2001 and the 'Bahagian Pembangunan Kesihatan Keluarga, Kementerian Kesihatan Malaysia' in 2008) note the option to give Paracetamol prophylaxis for childhood vaccinations, but neither promote nor discourage routine use of prophylaxis. (Jackson, Peterson, Dunn, Hambidge, Dunstan, Starkovich, Yu, Benoit, Dominguez-Islas, Carste, Benson, Nelson, 2011). The theoretical explanation was Paracetamol will inhibit the synthesis of Prostaglandin in the hypothalamus, thus inhibits the hypothalamic heat-regulating center and finally produces antipyeresis; as well as peripherally blocks pain impulse generation, thus producing analgesic effects (Drug Information Handbook, 2006). This explains why the use of Paracetamol during fever may be or may not be recommended since it may alter natural human body immune response although it may reduce pain.

The Medical News by The Lancet on $19^{\text {th }}$ Oct 2009 stated that 'Paracetamol, an antipyretic post vaccination is less likely to be counterproductive'. The proof is that antibody Geometric Mean Concentration (GMC) is lower significant in Paracetamol group than in control group (Medical News Today, 2009, Prymula, et. al, 2009). In fact, some evidence showed that prophylactic administration of an antipyretic drug around the time of vaccination may lower antibody responses to some vaccines (Immunisation Against Infectious Disease: How Vaccines Work?.The Green Book, 2006 and Jason and Philip, 2010). Besides, the vaccine itself may not be effective if Paracetamol is given at early stage to prevent fever following immunization. It may cause fewer antibody produced, thus it is possible that the vaccine may not work well (Immunisation Against Infectious Disease: How Vaccines Work?.The Green Book, 2006). Thus, this may warrant the use of Paracetamol post vaccination in infants since it may contradicts the Worlds Health Organization's Expanded Programme on Immunization main aim.

The reduction of fever and pain following infants immunization is a high priority for the international community. Ancient recommendation for fever and pain treatment need to be revised since treating fever at early stage and pain following infants immunization by Paracetamol may be questionable since it may causes the vaccine injected less effective (Prymula, et. al, 2009). Evidence-based health policies and programmes aiming to reduce fever and pain following infants immunization need reliable and valid information. Effective interventions to improve overall infants health need targeted health and social policies that are informed by reliable and valid epidemiological data. The author undertook a systematic review that aimed to estimate the effectiveness of Paracetamol for fever and natural intervention (in which breastfeeding) for pain following infants vaccination. Interventions used in the studies of antipyretic property of Paracetamol were placed in two (2) intervention categories: (i) administration of prophylactic Paracetamol and (ii) administration of Paracetamol during fever. Meanwhile, interventions used in the studies of analgesic property 
of breastfeeding were placed in two (2) categories: (i) breastfeeding (ii) held in mothers' arms but not fed. This study aims to determine the efficacy of breastfeeding as an analgesic properties and the efficacy as well as safety of Paracetamol as an antipyeretic properties post infants vaccination and provide evidence-based recommendations for clinical practice.

\section{METHOD}

\section{Search Strategies}

A wide range of medical, environmental and scientific databases were search to identify primary studies of the effects of breastfeeding before, during and after immunization as well as the effects of antipyretic agent following infants immunization in order to capture as many relevant citations as possible. The electronic searches were supplemented by hand searching of six (6) databases which accessed through EzProxy for Off Campus Access Online Database for International Islamic University Malaysia (IIUM) Students and Staffs in which via https://login .ezlib.iium.edu.my/login. The databases include Ovid LWW Total Access Collection and Medline, CINAHL (Cumulative Index to Nursing and Alled Health Literature) Plus with Fulltext, Science Direct, Proquest Dissertations and Theses, Proquest Education Journal and Proquest Health and Medical Complete. Additionally, manual reference checks of all articles on Paracetamol and breastfeeding post childhood vaccination published in English Language between 1978 and 2017. Two level of screening were used on 9614 citations. The keywords that were used include:

\begin{tabular}{|l|l|l|}
\hline Database searches & Items Measure & Keywords \\
\hline $\begin{array}{l}\text { Ovid LWW Total Access } \\
\text { Collection and Medline, } \\
\text { CINAHL Plus with }\end{array}$ & $\begin{array}{l}\text { 1) Pain } \\
\text { 2) Breastfeeding }\end{array}$ & $\begin{array}{l}\text { 'breastfeeding; pain or analgesia; } \\
\text { following or post; immunization } \\
\text { or vaccination; infant or newborn' }\end{array}$ \\
$\begin{array}{l}\text { Pulltext, Science Direct, } \\
\text { Theses, Proquest }\end{array}$ & 3) Fever and pain & $\begin{array}{l}\text { 'feverish or febrile or fever; } \\
\text { breastfeeding; temperature } \\
\text { Education Journal and } \\
\text { Proquest Health and } \\
\text { Medical Complete } \\
\text { (data collected from }\end{array}$ \\
published paper from 1987 & $\begin{array}{l}\text { 4) Paracetamol } \\
\text { following or post; immunization } \\
\text { until 2017) }\end{array}$ & $\begin{array}{l}\text { or vaccination; infant or newborn; } \\
\text { antibody' }\end{array}$ \\
\hline
\end{tabular}

Table 1: Keywords for Systematic Review

The titles and abstracts of the articles were scanned by two (2) reviewers (N. S. and S. H. S.). Articles selected by the reviewers were retrieved in full and assessed for eligibility by the two (2) reviewers. The reviewers did not contact the authors to identify additional studies 
but the reviewers referred to reference lists from the identified trials. The reviewers were not blinded to the authors or settings of the scanned articles.

\section{Study Selection: Inclusion Criteria}

Only reports with information on infants (for this study defined as up to 1 year of age) were included. All randomized trials and cohort (nonrandomized) studies that included a placebo or unexposed group were included for the determination of efficacy. Trials of different designs, however, were handled separately. The efficacy of breastfeeding as an analgesia and physical intervention of fever as antipyretic were reviewed for the immunization and/ vaccination procedure only. All prospective studies that reported data on variables of noxious stimuli with behavioral, physiologic, hormonal, and metabolic changes were included since infants respond to these variables. For determination of safety, all prospective studies were included. Paper that have funding sources also included in this study.

\section{Study Selection: Exclusion Criteria}

Reviews, meta-analyses, editorials, commentary or conference abstracts were excluded in this study. Meta-analysis was excluded in this study because it was not feasible due to extensive variation in study features and methodological quality (Coomarasamy A., Taylor R. \& Khan K. S., 2003)

\section{Data Collection and Analysis}

There were two reviewers in this study. The study from World Health Organization also included two reviewers for systematic review (Khan K. S., Wojdyla D., Say L., Gülmezoglu A. M., Look P. F. A. V., 2006). The first reviewer screened all titles and abstracts of papers identified by the literature search. The second reviewer handled duplicate screening on a random selection of found titles or abstracts. The disagreements were discusses between both reviewers. All studied that had been identified as potentially relevant were retrieved and read in full to determine eligibility for inclusion.

Data extractions were conducted by using a pre-defined data extraction template. Data that were extracted include design characteristics, study population and country, sample size, sample selection, age of participants, the exposure and outcome measures and results.

\section{Primary Outcome}

The primary outcome was pain and/ fever following infants immunization. Examples of validated observational measures for pain were a Douleur Aigue du Nouveau-ne (DAN) Scale, Facial Pain Rating Scale and Neonatal / Infant Pain Scale (NIPS), Children's Hospital of Eastern Ontario Pain Scale (CHEOPS) and cry duration. Examples of observational measures for fever were babies' fussiness and temperature reading more than and at $38^{\circ} \mathrm{C}$.

\section{Validity Assessment}

The included trials were not masked to the reviewers (N.S. and S.H.S.). The methodological quality of each study was assessed by two (2) independent reviewers using the Crowe Critical Appraisal Tool (CCAT) (Donnelly, Hickey, Burns, Murphy, Doyle, 2015) to investigate internal validity (the extent to which the information is probably free of bias) with the following attributes. The CCAT was developed based on a wide number of previous critical appraisal tools, general research methods theory and reporting guidelines (Donnelley et. al., 2015). The tool was validated and undergone testing for reliability and validity (Donnelly et. al., 2015). The CCAT appraised papers included in the review in eight (8) categories. This tool uses scoring system in which each category is scored from zero $(0)$ in which no evidence 
to five (5) in which highest evidence. Total scores of each study are presented as a percentage. The average scores of reviewers were reported.

\section{Data Abstraction}

Data from each eligible study were extracted individually on custom-made data-collection forms (designed specifically for each intervention) by two (2) reviewers (N.S. or S.H.S.), and the results were compared. The reviewers resolved any disagreements through discussion.

\section{Study Characteristics}

Characteristics of included studies as well as the country of being conducted were displayed in Table 2 (for effectiveness of breastfeeding) and 3 (for effectiveness of prophylactic Paracetamol and its safety). This study included research published in 1987 onwards.

\section{Data Synthesis}

Data syntheses were tabulated into study characteristics, quality and effects. The original review of summarizing the evidence from studies of variable design will provide details how the differences between study results were investigated and how they were summarized (Khan, 2003).

Authors of trials were not contacted for further details or provision of original data if the published report contained insufficient information. The study findings, as reported by the authors, were included in this review.

The data in this research cannot be pool due to not enough data regarding odd ratio or relative risk as well as confidence interval in each study.

\section{Secondary Outcomes}

Local and adverse reactions following infants immunization was reviewed in the study of prophylactic Pracetamol post infants vaccination.

\section{RESULTS}

\section{Effectiveness of breastfeeding as an analgesic property for pain following childhood vaccination}

\section{Study Descriptions}

Figure 1 presents a flow diagramme of the search strategy. After duplicates are removed the search retrieved 9504, of which 9481 are excluded (9400 on review of abstracts / title and a further 81 after full text papers assessment). 23 of reviewed full text articles and 19 were excluded because outcome and exposure not measured. Among these, one (1) was excluded because the age was not within inclusion criteria. Finally, data from three (3) journal articles included in the systematic review. 
Figure 1: Flow diagramme of research strategy for effectiveness of breastfeeding as pain intervention post childhood vaccination

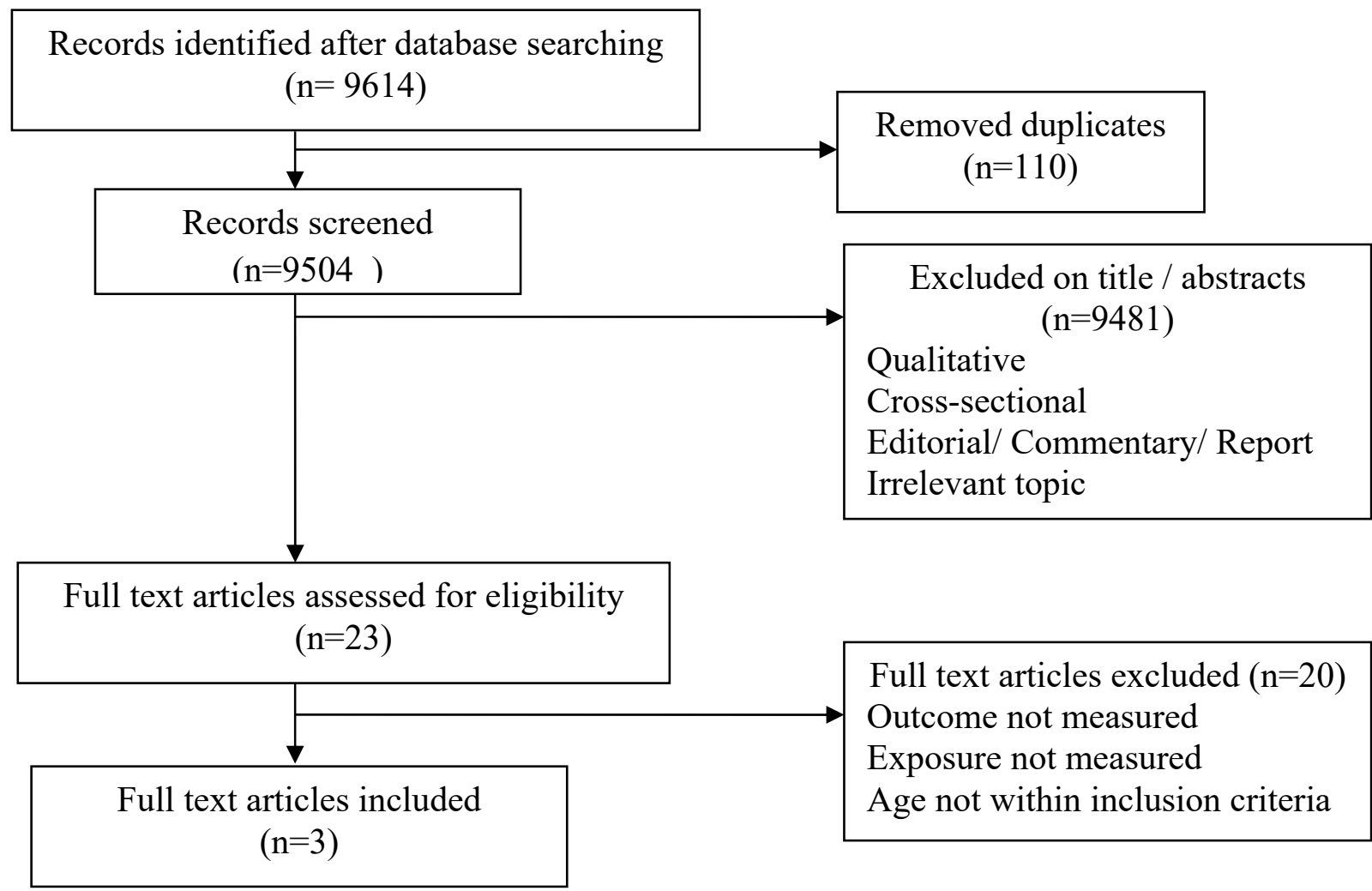

\section{Study Characteristics}

Overall, there were three (3) studies that met the inclusion criteria and eligible for study of the effectiveness of breastfeeding as an analgesic property for pain following immunization in infants. These researches were conducted mainly in East Coast country region which include one (1) in Iran, one (1) in Jordan and one (1) in Turkey. Studies began in 2007 and the latest study was in 2013.

These studies addressed two (2) of the intervention categories identified in the protocol: (i) breastfeeding or (ii) held in mothers' arms but not fed. All studies included age of babies not more than one (1) year.

The researcher included randomized control trial and quasi controlled trial that compared breastfeeding and combined interventions of interest with a placebo or control group for pain management during immunization in children aged from 0months to 1 year of age. Among these, there were two (2) studies that were randomized controlled trial and only one (1) study that was quasi controlled trial. The primary outcome measure for pain was made by health care worker or observer using observational methods; for example Douleur Aigue du Nouveau-ne (DAN) Scale, Facial Pain Rating Scale and Neonatal / Infant Pain Scale (NIPS), Children's Hospital of Eastern Ontario Pain Scale (CHEOPS) and cry duration. However, all of these studies did not mentioned the duration of breastfeeding.

Among these three (3) studies, one (1) did not contain information about receiving approval by institutional review board or ethics committee. On the other hand, two (2) of three (3) studies mentioned that they obtained approval from institutional ethics review board 
or committee. All of these studies mentioned that they obtained information consent from the mothers.

\section{Methodologic quality of the included studies}

The percentage of agreement on all key items for assessment of the methodologic quality of the three (3) studies was from $75 \%$ till $83 \%$; disagreements were resolved by consensus. Three (3) trials which include 316 infants aged zero (0) to 12 months examined the analgesic effects of breastfeeding.

\section{Effects of breastfeeding post infants vaccination}

In all three (3) studies, infants who were breastfeed before, during and after procedure were compared with infants who were not breastfed. The level of pain was measured using cry duration (Razek et. al., 2009 and Efe et. al., 2007), Neonatal Infant Pain Scale (NIPS) (Razek et. al., 2009), Douleur Aigue du Nouveau-ne (DAN) Scale (Modarres et. al, 2013), Facial Pain Rating Scale (FPS) (Razek at. al., 2009), Children's Hospital of Eastern Ontarion Pain Scale (CHEOPS) as well as behavioral changes (Efe et. al., 2007).

The reviews of all studies found significant benefit from breastfed in pain score and duration of crying as well as behavioral changes. Pain score of study by one (1) study revealed that significant lower pain score in which $\mathrm{p}<0.001$ in study by Razek et. al., 2009 for experimental group (breastfeeding group) than control group (not breastfed). One study by Razek et. al. in 2009 noted that FPS for intervention group represents little more pain $(38 \%)$ than control group which represents hurt even more Score 3 that indicate pain. Two (2) studies evaluated crying time and it was revealed that crying time was shorter in intervention group rather than control group (Razek et. al., 2009, Efe et. al., 2007). Other than that, among two (2) studies that evaluated behavioral changes in which heart rate and oxygen saturation, one (1) of them was found that statistically significant difference before and after immunization between intervention and control group $(p<0.005)$. The other one (1) study found that heart rate and oxygen saturation level almost same in both groups.

Breastfeeding had also been studied as an alternative to painful procedure during immunization recently, with positive outcomes. Studies had demonstrated that breastfeeding (Modarres et. al, 2013, Razek et. al., 2009 and Efe et. al., 2007), maternal holding (Efe et. al., 2007) and skin to skin contact (Razek et. al., 2009 and Efe,. et. al., 2007) statistically significantly reduced pain (Modarres et. al., 2013) and crying duration (Razek et. al., 2009 and Efe et. al., 2007) in children following immunization.

These studies showed that breastfeeding is effective as pain relief following immunization in infants

\section{Effectiveness of prophylactic Paracteamol as an antipyretic and analgesic properties as well as its safety for fever following childhood immunization}

\section{Study Descriptions}

Figure 2 presents a flow diagram of the search strategy. After duplicates were removed the search retrieved 1176, of which 1165 were excluded (1100 on review of abstracts / title and a further 65 after full text assessment). 11 of reviewed full text articles and two (2) were excluded because outcome and exposure not measured. Among these, five (5) were excluded because the age were not within inclusion criteria. Finally, data from four (4) journal articles were included in the systematic review. 
Figure 2: Flow diagramme of research strategy for effectiveness of prophylactic Paracetamol as fever reduction post childhood vaccination

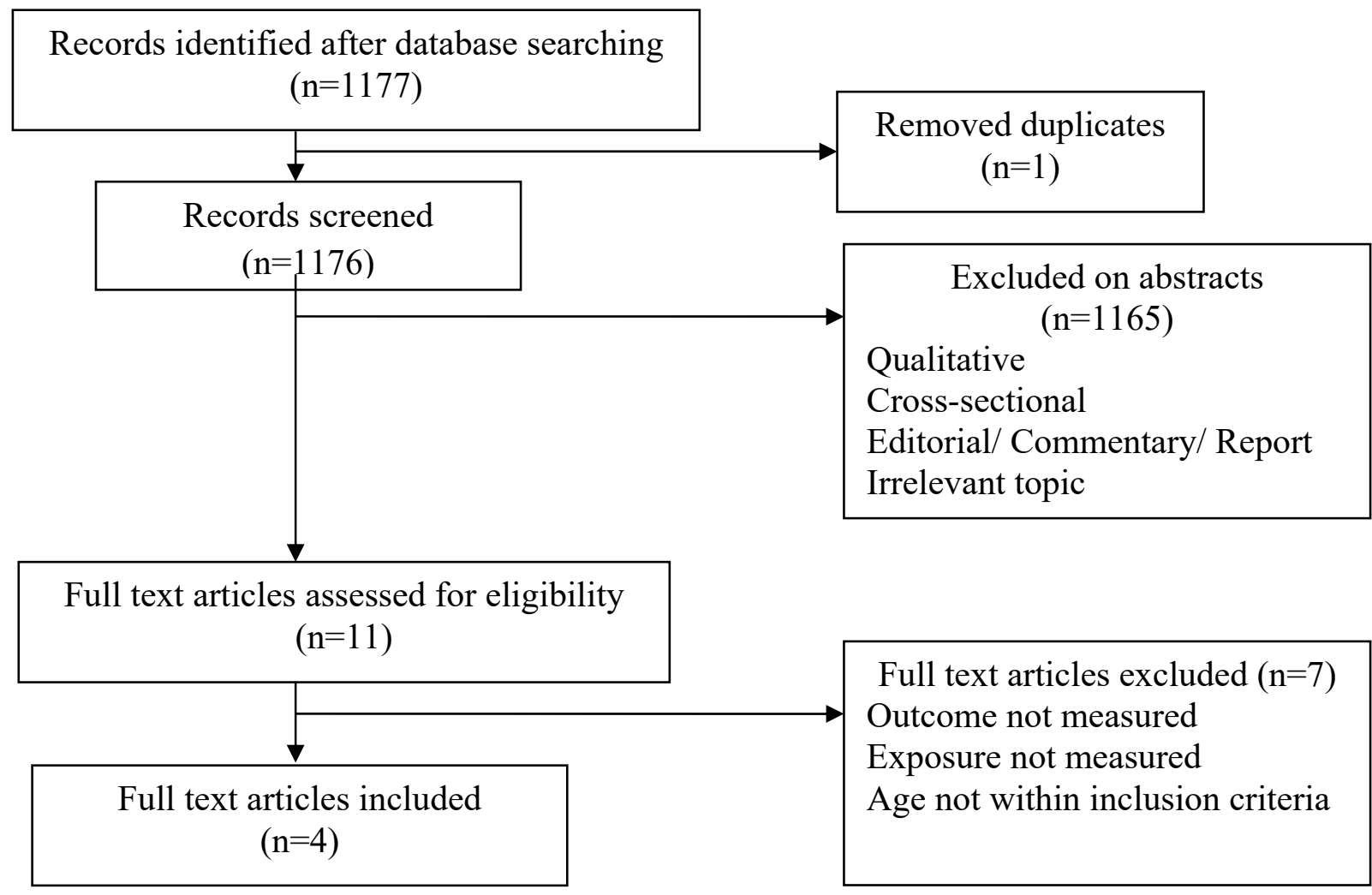

\section{Study Characteristics}

Overall, there were four (4) studies were assessed as being of sufficient quality to be included in the review. These researches were conducted mainly in Europe and East Coast country region which include one (1) in Czech Republic, one (1) in United States of America (USA), one (1) in Germany and one (1) in Finland. Studies began in 1988 and the latest study was in 2013.

As mentioned before, these studies addressed two (2) intervention categories: (i) administration of prophylactic Paracetamol and (ii) non-prophylactic Paracetamol for fever following childhood immunization.

All of these studies evaluated either the child was having fever or not (Rose et. al, 2013, Jackson et. al, 2011, Prymula et. al., 2009 and Uhari et. al., 1988), only one (1) study evaluated local systemic reactions (Rose at. al., 2013), two (2) studies evaluated adverse reactions (Rose et. al., 2013 and Uhari et. al., 1988) and only one (1) study evaluated baby condition (Jackson et. al., 2011) as well as only two (2) studies evaluated antibody of children (Prymula et. al., 2009 and Uhari et. al., 1988). All studies included age of babies from about six (6) weeks to around one (1) year of age (Rose et. al, 2013, Jackson et. al., 2011, Prymula et. al., 2009 and Uhari et. al., 1988). All of these studies also included in the systematic review.

The researcher included all randomised controlled trial that compared prophylactic Paracetamol use and/ no prophylactic Paracetamol use post infants vaccination. The primary outcome measure for fever was made by parents completed the diary and/ questionnaires given by the researcher of the study, 
Among these four (4) studies, three (3) of them mentioned that they obtained approval from institutional ethics review board or committee (Rose et al., 2013, Jackson et. al, 2011 and Prymula et. al., 2009). All of these studies mentioned that they obtained information consent from parents and/ legal guardian except the study by Uhari et. al (1988) did not mentioned they obtained consent from guardians, however they had obtained Ethical Approval from Medical Faculty of Oulu University.

\section{Methodologic quality of the included studies}

The percentage of agreement on all key items for assessment of the methodologic quality of the four (4) studies were ranging from $65 \%$ till $88 \%$; disagreements were resolved by consensus. Four (4) trials which include 1156 infants aged zero (0) to 12 months of age examined the antipyretic effect of Paracetamol.

\section{Effect of prophylactic PCM for fever and pain following childhood immunization}

All studies compared children receiving prophylactic or non-prophylactic PCM post vaccination. Fever was measured using body temperature $\geq 38 \mathrm{C}$ or $>39.5 \mathrm{C}$ of axillary or rectal temperature, meanwhile baby condition was measured by the appearance of fussiness.

The reviews of two (2) studies found significant benefit from prophylaxis Paracetamol in fever (Rose et. al., 2013 and Prymula et. al., 2009) and only one (1) study found significant benefit from prophylaxis Paracetamol in fussiness (Jackson et. al., 2011). On the other hand, there was one (1) study found not signifiant benefit from prophylaxis Paracetamol in fever (Uhari et. al., 1988).

\section{Local and adverse reactions following immunization}

Other than that, recent one (1) study found that local systemic reactions were less frequent in prophylaxis group, but no significant difference between groups (Rose et. al., 2013). In contrast, there was none study showed that there was significant reductions in local systemic reactions of prophylactic group (Jackson et. al, 2011, Prymula et. al., 2009 and Uhari et. al., 1988).

Besides, there was one (1) study stated that no vaccine-related serious adverse event reported (Rose et. al., 2013), and there was none study mentioned that prophylactic PCM can significantly reduced frequency and severity of common adverse reactions (Rose et. al, 2013, Jackson et. al, 2011, Prymula et. al., 2009 and Uhari et. al., 1988). The study by Uhari et. al. in 1988 revealed that no significant difference in occurrence of minor adverse events.

\section{Safety of prophylactic Paracetamol post infants vaccination}

Other than that, there were two (2) studies evaluate the safety of prophylactic Paracetamol (Prymula et. al., 2009 and Uhari et. al., 1988). These studies revealed different outcomes, in which study by Prymula et. al. in 2009 found that antibody responses to several antigens were reduced significantly, and the other study by Uhari et. al. in 1988 found that antibody titres to DTP bacteria of placebo and PCM not differ significantly. The study by Prymula et. al. in 2009 also noted that prophylactic Paracetamol at time of vaccination should not routinely recommended although febrile reactions significantly reduced since antibody responses to several antigens were reduced significantly.

Prophylactic Paracetamol had been studied to have beneficial effects as antipyretic property post vaccination in children. However this outcome is questionable since there were also studies that rejected the benefit of prophylactic Paracetamol. Other than that, there was one (1) study found that prophylactic Paracetamol may significantly reduced the antibody of infants (Prymula et. al., 2009). Additionally there was one (1) study by Jackson et. al. in 2011 
was stopped because the result of study by Prymula et. al. in 2009. The study by Jackson et. al. in 2011 also noted that the potential benefit of Paracetamol prophylaxis in reducing the risk of fever and associated adverse events following contemporary infants immunizations appear to be outweighted by the potential harmful effects of Paracetamol prophylaxis on vaccine immune responses.

\section{DISCUSSION}

Paracetamol was use as an antipyeretic agent and analgesic post vaccination in infants. However, its use seems questionable since in theory the use of Paracetamol at early stage of fever may alter the vaccine function and causes vaccine less effective (Prymula, et. al, 2009). Theoretically, the use of Paracetamol may interferes natural body immune response by inhibiting Prostaglandins (PGs) which involve in natural human body defense mechanisms. Meanwhile, most vaccines injected to the child are originated from the live attenuated organism itself (organism that may cause infection) in which they work by replicating of the live organisms over days or weeks thus covering the immunity.

Prophylactic antipyretic of Paracetamol significantly reduced the febrile reactions of $\geq 38^{\circ} \mathrm{C}$ after vaccinations. There were statistically significant differences in antibody responses between two groups in which lower in prophylactic Paracetamol group. Recent one (1) study showed that there were significant reductions in the local and systemic symptoms in prophylaxis group, but no significant difference between groups (Rose et. al., 2013).

Only two (2) trials studied the antibody response (Prymula et. al, 2009 and Uhari, et. al. 1988), thus the data cannot be pooled. Studies used different doses/ schedules antipyretic administration as well as age of participants or timing of administration also markedly differed among studies.

There were none of studies that were identified in the literature search evaluated the effectiveness of oral analgesic in which Paracteamol for immunization pain (Shah, Taddio, Rieder, 2009). Pediatricians may recommend oral analgesics to parents as a pain-relieving intervention for vaccine injection pain (Shah et. al., 2009). However, no evidence was found to recommend the use of either agent as a method of pain relief for vaccine injections. There was no study of Paractemol effects on vaccine injection pain was identified, however this agent was widely used. Thus, a study that addresses this issue may be warranted.

This study found that breastfeeding before, during and after immunization reduced pain, as assessed using cry duration, DAN scale, FPS, NIPS, CHEOPS and or behavioral changes (heart rate and oxygen saturation. The proposed mechanisms of breastfeeding provides analgesia include (i) breastfeeding, (ii) maternal holding and skin to skin contact (Efe et. al., 2007).

The findings of systemic review were consistent with the effectiveness of breastfeeding as an analgesic property in reducing pain of injection immunization in neonates (Shah et. al., 2009). Breastfeeding is a natural, cost-neutral, time-efficient, and convenient intervention that could be easily adopted from the perspectives of health care providers and parents (Shah et. al., 2009). Other than nutritional and psychological value of breastfeeding, the analgesic properties may encourage more mothers to breastfeed (Shah et. al., 2009). 


\section{LIMITATION}

Methodologic challenges and limitations of this review include the small number of studies for breastfeeding interventions, small sample size, limited age range of participants, limited number of vaccines evaluated and variability in pain assessments. The included trials used various methods of assessing pain in infants, which made it difficult to combine and contrast the results.

\section{RECOMMENDATION FOR FUTURE RESEARCH}

Finally, in deciding Paracetamol to be rational use following infants immunization, it may need for further research which include in depth quantitative and qualitative studies to identify specific problem and causes regarding this issue.

Based on the researcher's review, areas for future research were identified. The role of expressed breast milk has not been studies, and further research is needed. Finally, studies addressing whether the gap between research findings and clinical practice can be narrowed by communication and dissemination strategies aimed at practitioners, professional groups, and families will be important in establishing the common goal of pain-free, tolerable, and effective immunization for infants.

Future trials should focus on the timing (before, with or after) and route (oral or rectal) of administration of Paracetamol as well as on the subgroup of infants (term or preterm) for any correlation with the immune response. Future trials should focus on trial examining the prophylactic effect of Paracetamol post vaccination antibody response since there was lack of studies regarding this issue. The mechanism underlying the reduction in immune / antibody response should also be explored. Trials should also be conducted in developing countries where over-the-counter use of antipyretics (including prophylactic) are common. Other cofounding factors that might affect the antibody response such as infants sleep post-immunization should also be studied.

\section{CONCLUSION}

In identifying the problem in drug use, this preliminary research need to be conducted as guided by World Health Organization in deciding the relevancy of the supply of Paracetamol post all types of infants immunization.

The relevancy of giving Paracetamol post all types of vaccination may be questionable since the the safety issue of this intervention may be arised.

Although prophylactic antipyretic Paracetamol administration leads to relief of local and systemic symptoms after vaccinations, there was a reduction in antibody responses to some vaccine antigens. Future trials and surveillance programs should also aim at assessing the effectiveness of programs where prophylactic Paracetamol is given. The timing of administration of Paracetamol should be discusses with the parents after explaining the benefits and risks.

Breastfeeding before, during and after immunization are recommended for pain reduction as systematic review of this study showed its proven effectiveness. 


\section{REFERENCES}

Abad-Diez J.M., Calderon-Larranaga A., Poncel-Falco A., Poblador-Plou B., Calderon-Meza J.M., Sicras-Mainar A., Clerencia-Sierra M., and Prados-Torres A. (2014). Age and gender differences in the prevalence and patterns of multimorbidity in the older population. Retrieved April 11, 2015. 10.1186/1471-2316-14-75.

Alesandro R., Vladamir K., Oliver S., Thomas R., Heinz B., Ryan T., (November 2012). Ageand gender-related prevalence of multimorbidity in primary care: the swiss fire project. $B M C$ Family Practice. 10.1186/1471-2296-13-113.

American Pharmacists Association. (2006). Acetominophen.Drug Information Handbook. United States of America: Lexi-comp.

Bahagian Pembangunan Kesihatan Keluarga. (2008). Panduan Program Imunisasi Kebangsaan Kanak-Kanak Untuk Anggota Kejururawatan.Kuala Lumpur: Kementerian Kesihatan Malaysia.

Centers for Disease Control and Prevention. (2014). All vaccines cause side effects. United States of America: Department of Health and Human Sciences.

Centre for Clinical Practice at NICE. (2013). Feverish illness in children Assessment and initial management in children younger than 5 years. United Kingdom: National Institute for Health and Care Excellence.

Chiew S. N. (2014). MADRAC Reports [Quest 2 System (Survaillence \& Pharmacovigillance System]. Petaling Jaya: National Pharmaceutical Control Bereau.

Christoper L. Cody, Larry J., Baratlt, James D., Cherry S., Michael M., Charles R., Manclark, )November 1981). Nature and rates of adverse reactions associated with DTP and DT immunizations in infants and children. Official Journal of the American Academy of Peadiatrics, Vol. 68.

Clinical Practice Guideline Childhood Immunization, MOH of Malaysia 2004.

College of Paediatrics (2001), Malaysian Immunization Manual. Kuala Lumpur: Academy of Medicine Malaysia.

Cooper C., Atkinson E.J., O'fallon W.M., Melton III C.J. (1992). Incidence of Clinically Diagnosed Vertebral Fractures: A Population-Based Study in Rochester, Minnesota, 19851989. Minnesota: Department of Health Sciences Research, Mayo Clinic and Foundation.

Coomarasamy A., Taylor R. \& Khan K. S., (2003). A systematic review of postgraduate teaching in evidence-based medicine and critical appraisal. Medical Teacher, Vol. 25.

Das R. R., Panighari I., Naik S. S., (2014). The effect of prophylactic antipyretic administration on post-vaccination adverse reactions and antibody response in children: a systematic review. PLOSONE, Vol. 9. 
Deborah G., Hirtz, Karin B., Nelson, Jonas H., Ellenberg, Bethesda, (April 1982). Seizures following childhood immunization. The Journal of Peadiatrics, Vol. 102, No. 1, pp14-18.

Department of Health. (2006). Immunisation Against Infectious Disease: How Vaccines Work?.The Green Book. Great Britain.

Dickersin K. (2002). Systematic reviews in epidemiology: why we so far behind?. Great Britain: International Epidemiological Association.

Dilli D., Kucuk I. G., Dallar Y., (2008). Interventions to reduce pain during vaccination in infancy. The Journal of Peadiatrics.

Donnelly N., Hickey A., Burns A., Murphy P., Doyle F. (2015). Systematic Review and Meta -Analysis of the Impact of Carer Stress on Subsequent Institutionalisation of CommunityDwelling Older People. PlosOne.

Efe E., Ozer Z. C., (2007). The use of breast-feeding for pain relief during neonatal immunization injections. Applied Nursing Research.

Flegal K.M., Caroll M.D.,Kuczmarski R.J., Johnson C.L. (1997). Overweight and obesity in the United States: Prevalence and Trends, 1960 - 1994. USA: National Center for Health Statistics, Center for Disease Control and Prevention.

Flegal K.M., Caroll M.D., Ogden C. L., Johnson C.I. (2002). Prevalence and Trends in Obesity Among US Adults, 1999-2000. USA: American Medical Association.

Ford E.S., Giles W. H., Dietz W.H., (2002). Prevalence of Metabolic Syndrome Among Adults. USA: American Medical Association.

Franck L. S., GHreenberg C. S., Stevens B., (2000). Pain assessment in infants and children. Pediatric Clinic of North America. Volume 47. Number 3.

Guo B., Page A., Wang H., Taylor R., McIntyre P., (2013). Systematic review of reporting rates of adverse events following immunization: An international comparison of postmarketing surveillance programs with reference to China. Vaccine Volume 31, Issue 4, pages 603-617

Harrison D., Sampson M., Reszel J., Abdulla k., Barrowman N., Cumber J., Fuller A., Li C., Nicholls S., Pound C. M., (2014). Too many crying babies: a systematic review of pain managemant practices during immunizations on YouTube. BMC Pediatrics.

Hauser W.A., Annerges J.F., Kurland L.T. (1992). Incidence of Epilepsy and Unprovoked Seizures Center, College of Physicians 1935-1984. New York: Q.H. Sergievsky Center, College of Physicians and Surgeons, Columbia University, Texas: School of Public Health, University of Texas \& USA: Section of Medical Research, Mayo Clinic.

Health Informatics Centre, Palanning \& Development Division, Ministry of Health Malaysia. (2011). Annual Report Family Health 2011. Malaysia: Health Information \& Management System. 
Health Informatics Centre, Palanning \& Development Division, Ministry of Health Malaysia. (2012). Annual Report Family Health 2012. Malaysia: Health Information \& Management System.

Health Informatics Centre, Palanning \& Development Division, Ministry of Health Malaysia. (2013). Annual Report Family Health 2013. Malaysia: Health Information \& Management System.

Hodges FM, SvobodaJS, Van HoweRS. Prophylactic interventions on children: Balancing human nghts with public health. Med Ethics.2002;28:10-16.

Hoek H.W., Hoeken D.V. (2003). Review of the Prevalence and Incidence of Eating Disorders. New York: Department of Epidemiology, Mailman, School of Public Health, Columbia University \& The Netherlands: Parnassia Psychiatric Institute.

Hunter J., (1973). Study of antipyretic therapy in current use. Archives of Disease in Childhood.

Imam Ibn Qayyim Al-Jauzyah. (2003). Curing Fever. Healing with Medicine of the Prophet. Riyadh: Maktaba Darussalam.

Ipp M. M., FGold R., Greenberg S., Goldbach M., Kupfert B. B., Llyold D. D., Maresky D. C., Saunders N., Wise S. A., (1987). Acetaminophen prophylaxis of adverse reactions following vaccination of infants with diphteria-pertusis-tetanus toxoids-polio vaccine. Pediatr Infect Dis J., 6: 721-725, 1987.

Jackson LA, Peterson D, Dunn J, Hambidge SJ, Dunstan M, Starkovich P, Yu O, Benoit J, Dominguez-Islas CP, Carste B, Benson P, Nelson JC (2011). A Randomized PlaceboControlled Trial of Acetominophen for Prevention of Post-Vaccination Fever in infants. PLoS $O N E, 6(6)$ retrieved from www.plosone.org.

Janice E. Sullivan, MD, Henry C. Farrar, MD, and the Section on Clinical Pharmacology and Therapeutics, and Committee on Drugs (2011). Clinical Report: Fever and Antipyretic Use in Children, American Academy of Peadiatrics.

Jason H Homme, Philip R Fischer (2010), Prophylactic Paracetamol at the time of infant vaccination reduces the risk of fever but also reduces antibody response, Evidence Based Medicine.

Jason L., Bruce H., Pomeraz, Paul N., Corey, (April 1998). Incidence of adverse drug reactions in hospitalized patients. JAMA, Vol. 279, No. 15.

Jensen J. F., Tonnesen L. L., Soderstrom M., Thorsen H., Siersma V., (2010). Paracetamol for feverish children: parental motives and experiences. Scandinavian Journal of Primary Health Care. 28: 115-120.

Jose M. A., Amaia C., Antonio P., Betriz P., Jose M. C., Antoni S., Mercedes C., Alexandra P., (June 2014). Age and gender differences in the prevalence and patterns of multimorbidity in the older population. Biomed Central, 2014 14:75. 
Katrin S. K., Michael M., Michael B., Marcy C. J., Ron D., John H., David N., Edward R., the Brighton Collaboration Fever Working Group, (March 2004). Fever after immunization: Current comcepts and improved future scientific understanding. USA: Infectious Diseases Society of America.

Jackson L. A., Dunstan M., Starkovich P., Dunn J., Yu O., Nelson J. C., Rees T., Zavitkovsky A., (2005). Prophylaxis with acetaminophen or ibuprofen for prevention of local reactions to the fifth diphteria-tetanus toxoids-acelular pertusis vaccination: A randomised, controlled trial. Pediatrics: Official Journal of the American Academy of Pedistrics.

Jackson L. A., Peterson D., Dunn J., Hambidge S. J., Dunstan M., Starkovich P., Yu O., Benoit J., Dominguez-Islas C. P., Carste B., Benson P., Nelson J. C., (2011). A randomised placebo-controlled trial of acetaminophen for prevention of post-vaccination fever in infants. PLOSONE.

Khan K. S., Kunz R., Kleijnen J., Antes G., (2003). Five steps to conducting a systematic review. Journal of the Royal Society of Medicine.

Khan K. S., Wojdyla D., Say L., Gülmezoglu A. M., Look P. F. A. V., (2006), WHO analysis of causes of maternal death: a systematic review. Lancet.

Kids Health from Nemours (2013). Fever and Taking Your Child's Temperature. The Nemours Foundation retrieved from www.kidshealth.org.

King H., Aubert R.E., Herman W.H. (1998). Global Burden of Diabetes, 1995-2025. Diabetes Care. Volume 21, Number 9.

Knowler W.C., Barrett-Connor E., Fowler E., Hamman R.F., Lachin J.M., Walker E.a., Nathan D.M. (2002). Incidence of Type 2 Diabetes with Lifestyle Intervention in Metformin. USA: National Institute of Health.

Lazarou J., Pomeranz B.H., Corey P.N. (1998). Incidence of Adverse Drug Reactions in Hospitalized Patients. Toronto: Department of Zoology, Psysiology and Public Health Sciences, University of Toronto.

Lewis K., Cherry J. D., Sachs M. H., Woo D. B., Hamilton R. C., Tarle J. M., Overturf G. D., (1988). The effect of prophylactic acetaminophen administration on reactions to DTP vaccination. $A J D C$-Vol 142.

Manley J., Taddio A., (2007). Acetaminophen and ibuprofen for prevention of adverse reactions associated with childhood immunization. The Annals of Pharmacotherapy.

Marie R., Griffin, Wayne A. R., Edward A., Mortiner, Gerald M., Fenichel, William S., (March 1990). Risk of seizures and encephalopathy after immunization with the diphtheriatetanus-pertusis vaccine. JAMA, Vol. 263, No. 12.

Marla J., Friedman D.O., Ghazala Q., Sharieff M.D., (2006). Seizures in Children. Pediatr Clin N Am, Vol 53, 257-277. 
Mathew P. J., Mathew J. L., (2003). Assessment and management of pain in infants. Postgrad Med J. 79: 438-443.

Medical News Today, 19 Oct. 2009 (Get source from research: "Effect of prophylactic Paracetamol administration at time of vaccination on febrile reactions and antibody responses in children: two open-label, randomised controlled trials."Roman P. et. al, The Lancet, Volume 374, Issue 9698, Pages 1339 - 1350, 17 October 2009).

MedlinePlus. (last updated January 2015). U. S. National Library of Medicine: Trusted Health Information for You. United States of America: Department of Health and Human Services, National Institute of Health.

Modarres M., Jazayeri A., Rahnama P., Montazeri A., (2013). Breastfeeding and pain relief in full-term neonates during immunization injections: a clinical randomised trial. BioMed Central.

Naiji L., Yu H., Tian C., Douglas D., Gunzler, Yinglin X., Julia Y., Lin, and Xin M. T., (2013). Power Analysis for Cross-Sectional and Longitudinal Study Designs. Shanghai Archieves of Psichiatry. Aug; 25(4): 259-262.

Nicola P., Klein, Bruce F. W., Katherine Y., Edwin L., Martin K., Paula R., Roger B., Simon H., James N., Allison N., Edward A. B., Tracy L., James B., Eric W., (2010). Measles,Mumps-Rubella-Varicella Combination Vaccine and the Risk of Febrile Seizure. Pediatrics. Volume 126, Number 1.

Nelson K. B., Ellenberg J. H., (1978). Prognosis in children with febrile seizures. Peadiatrics. 61: 720-7.

Offringa M., Bossuyt P. M., Lubsen J., (1994). Risk factors for seizure recurrence in children with febrile seizures: a pooled analysis of individual patient data from five studies. Journal of Peadtiatrics. 124: 574-84.

Ogden C.L., Caroll M.D., Curtin L.R., McDowell M.A., Tabak C.J., Flegal K.M. (2006). Prevalence of Overweight and Obesity in the United States, 1999-2004. USA: American Medical Association.

Paddy F., Simon P., Alaric C., Audrey F., James N., Peter M. C., Marie R., Eliza B. M., (March 1995). A new method for active surveillance of adverse events from diphtheria, tetanus, pertusis and measles/mumps/rubella vaccines. The Lancet, Vol. 345.

Pisacane A., Continision P., Palma O., Cataldo S., Michele F. D., Vairo U., (2010). Breastfeeding and risk for fever after immunization. American Academy of Peadiatrics. e1448-e1452.

Prymula, R., Siegrist, C. A., Chlibek, R., Zemlickova, H., Vackova, M., Smetana, J., \& Schuerman, L. (2009). Effect of prophylactic Paracetamol administration at time of vaccination on febrile reactions and antibody responses in children: two open-label, randomised controlled trials. The Lancet,374(9698), 1339-1350. 
Razek A. A., El-Dein N. A., (2009). Effect of breast-feeding on pain relief during infant immunization injections. International Journal of Nursing Practice.

Riddell R. P., Racine N., Turcotte K., Uman L. S., Horton R., Osmun L. D., Kohut S. A., Stuart J. S., Stevens B., Lisi D., (2011). Nonpharmacological management of procedural pain in infants and young children: An abridged Cochrane review. Pain Research and Management : The Journal of the Canadian Pain Society.

Rizza A., Kaplan V., Senn O., Roseman O., Bhend H., Tandjung R., on behalf of the FIRE study group. (2012). Age-and gender-related prevalence of multimorbidity in primary care: the swiss fire project. Switzerland: Division of Internal Medicine, University Hospital Raemistrasse 100, Zurich.

Rose W., Kirubakaran C., Scott J. X., (2005). Intermittent clobazam therapy in febrile seizures. Indian Journal of Peadiatrics. 72: 31-3.

Rose M. A., Juergens C., Schmoele-Thoma B., Gruber W. C., Baker S., Zielen S., (2013). An open-label randomised clinical trial of prophylactic paracetamol coadministered with 7-valent penumococcal conjugate vaccine and hexavalent diphteria toxoid, tetanus toxoid, 3component acellular pertusis, hepatitis B, inactivated poliovirus, and Haemophilus influenzae type b vaccine. BioMed Central.

Shah, V., Taddio, A., \& Rieder, M. J. (2009). Effectiveness and tolerability of pharmacologic and combined interventions for reducing injection pain during routine childhood immunizations: systematic review and meta-analyses. Clinical therapeutics, 31, S104-S151.

Sullivan J. E. \& Farrar H. C., Section on Clinical Pharmacology and Therapeutics and Committee on Drugs (2010). Clinical Report: Fever and Antipyretic Use in Children. USA: American Academy of Pediatrics.

Taddio A., Appleton M., Bortolussi R., Chambers C., Dubey V., Halperin S., Hanrahan A., Ipp M., Lockett D., MacDonald N., Midmer D., Mousmanis P., Palda V., Pielak K., Riddell R. P., Rieder M., Scott J., Shah V., (2010). Reducing the pain of childhood vaccination: an evidence-based clinical practice guideline. Canadian Medical Association Journal.

Taddio A., Appleton M., Bortolussi R., Chambers c., Dubey V., Halperin S., Hanrahan A., Ipp M., Lockett D., MacDonald N., Midmer D., Mausmanis P., Palda V., Pielak K., Riddell R. P., Rieder M., Scott J., Shah V., (2010). Reducing the pain of childhood vaccination: an evidence-based clinical practice guideline. Canadian Medical Association Journal.

Taddio, A., Chambers, C. T., Halperin, S. A., Ipp, M., Lockett, D., Rieder, M. J., \& Shah, V. (2009). Inadequate pain management during routine childhood immunizations: the nerve of it. Clinical therapeutics, 31, S152-S167.

Taddio A., Ohlsson A., Einarson T. R., Stevens B., Koren G., (1998). A systematic review of lidocaine-prilocaine (EMLA) in the treatment of acute pain in neonates. PEDIATRICS Vol. 101. No. 2. 
Tansky C., Lindberg C. E., (2010). Breastfeeding as a pain intervention when immunizing infants. The Journal of Nurse Practitioners.

Tonia J., Steven J. J., (2007), Childhood febrile seizures overview and implications. International Journal of Medical Sciences, 4(2): 110-114.

Tozzi A., Law B., Keller-Stanislawski B., Asturias E., Gold M., Labadie J., Halsey N., Evans S., Amarasinghe A., Balakrishnan M. R. and Zuber P. (2013). Causality Assessment of Adverse Event Following Immunization (AEFI). World Health Organization.

Uhari M., Hietala J., Viljanen M. K., (1988). Effect of prophylactic acetaminophen administration on reaction to DTP vaccination. Acta Paedistr Scand 77: 747-751.

Unit Farmakovigillan dan Keselamatan Vaksin. (2010). Garispanduan Farmakovigilans Keselamatan Vaksin. Biro Pengawalan Farmasi Kebangsaan, Kementerian Kesihatan Malaysia.

Vanderpump M.P.J., Tunbridge W.M.G., French J.M., Appietant D., Bates O., Clark F., French J.M., Appietant D., Bates O., Clark F., Evans J.G., Hasan D.M., Rodgers H., Tonbridge F., and Young E.T. (1995). The incidence of thyroid disorders in the community: a twenty-year follow-up of the Whickham Survey. UK: University of Oxford.

Vainio A., Aurinen A., with members of Symptom Prevalence Group. (1996). Prevalence of Symptoms Among Patients with Advanced Cancer: An International Collaborative Study. Switzerland: Cancer and Palliative Care Unit, World Health Organization.

Watts R., Robertson J., Thomas G., (2003). Nursing management of fever in children: A systematic review. International Journal of Nursing Practice.

Wild S., Roglic G., Green A., Sicree R., King H. (2004). Global Prevalence of Diabetes. USA: American Diabetes Association.

Western Australia Vaccine Safety Surveillance: Annual Report, 2013. Department of Health, Department of Western Australia: Prevention and Control Program, Communicable Disease Control Directorate, Department of Health, Western Australia.

World Health Organization (WHO) website, updated 2015.

www.healthadel.com/vaccines-and-acetaminophen-given-together/

www.health.gov.on.ca/en/public/publications/immune/dtapipvhib-aspx, 2015.

www.health.gov.on.ca/en/public/publications/immune/mmr, 2015.

Xiao-Y., Yan L., Jie-li G., Ya-Meng S., Yang C., Guo-Wen S., Qun X., Yan-Sheng L., (June 2012). Age -and gender-specific prevalence of risk factors in patients with first-ever ischemic stroke in China. Stroke Resp. Treat., PMC 3385649.

Yalcin S. S., Gumus A., Yurdakok K., (2008). Prophylactic use of acetaminophen in children vaccinated with diphteria-tetanus-pertusis. World J. Pediatr. 
Yao X., Lim Y., Geng J., Sun Y., Chen Y., Shi XU O., Ci Y. (2012). Age-and Genderspecific Prevalence of Risk Factors in Patients with First-Ever Ishchemic Stroke in China. Retrieved April 11, 2015. P.MCID: PMC3385649.

Zhou W., Pool V., Iskander J. K., English-Bullard R., Ball R., Wise R. P., Haber P., Pless R. P., Mootrey G., Ellenberg S. S., Braun M. M., Chen R.T., (2003). Surveillance for Safety After Immunization: Vaccine Adverse Event Reporting System (VAERS), United States, 1991-2001. USA: Centers for Disease Control and Prevention (CDC).

Acknowledgement: The author would like to thank the Director General of Health for his permission to publish this paper. The author also would like to thank International Islamic University Malaysia, Kuantan Campus for giving support in conducting this project.

\section{Registrations:}

i) Systematic Review on the Relevancy of Paracetamol Post Infants Vaccination [KKM.NIHSEC.800-4/4/1 Jld. 53(08)]

ii) Medical Research Ethics Committee (MREC): Clinical use of Paracetamol Post Infants Vaccination [NMRR-17-2573-38799(IIR)] 


\section{APPENDIX I}

Table 2: Summary of Relevant Research on Effectiveness of Breastfeeding Used as an Intervention to Decrease Pain in Infants

\begin{tabular}{|c|c|c|c|c|c|c|c|c|c|}
\hline No. & $\begin{array}{l}\text { Author; country; } \\
\text { year of publication }\end{array}$ & $\begin{array}{l}\text { Research } \\
\text { design }\end{array}$ & $\begin{array}{l}\text { Study population; } \\
\text { care recipient \% } \\
\text { boys; care recipient } \\
\text { age mean (SD) }\end{array}$ & $\begin{array}{l}\text { Sample } \\
\text { size: } \\
\text { baseline; } \\
\text { follow- } \\
\text { up }\end{array}$ & $\begin{array}{l}\text { Exposure } \\
\text { measure }\end{array}$ & $\begin{array}{l}\text { Outcome } \\
\text { measure }\end{array}$ & $\begin{array}{l}\text { Quality } \\
\text { score } \\
(\%)\end{array}$ & Statistical results & Conclusion \\
\hline 1 & $\begin{array}{l}\text { Modarres, Jazayeri, } \\
\text { Rahnama, Montazeri, Iran, } \\
2013 \\
\text { [Funding Source: } \\
\text { Instituitional Review } \\
\text { Board of the Tehran } \\
\text { University of Medical } \\
\text { Sciences] }\end{array}$ & $\begin{array}{l}\text { True } \\
\text { experiment: } \\
\text { Placebo } \\
\text { controlled } \\
\text { trial }\end{array}$ & $\begin{array}{l}\text { Full term neonates } \\
\text { breastfed } 2 \text { minutes before, } \\
\text { during and after Hepatitis } \\
\text { B immunization or held in } \\
\text { mothers' arms but not fed; } \\
83 \% \text { boys; } 39.4 \text { (1.2) in } \\
\text { control group and } 39.1 \\
\text { (1.3) in experimental group } \\
\text { weeks }\end{array}$ & $\begin{array}{l}130 ; 130 \\
130\end{array}$ & $\begin{array}{l}\text { 1) Pain score } \\
\text { measured } \\
\text { using DAN } \\
\text { scale (Facial } \\
\text { expressions, } \\
\text { limb } \\
\text { movements } \\
\text { and vocal } \\
\text { expression) }\end{array}$ & Pain score & 75 & 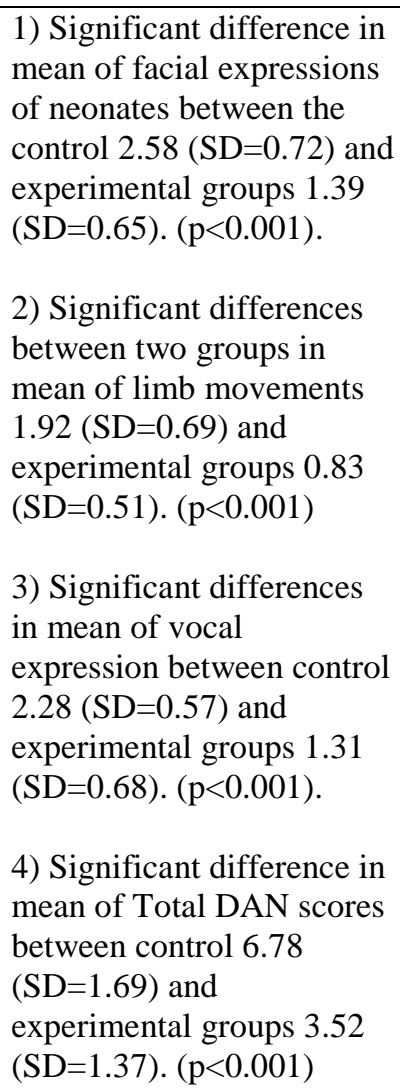 & $\begin{array}{l}\text { Breastfeeding } \\
\text { reduces pain } \\
\text { and is } \\
\text { effective way } \\
\text { for pain relief } \\
\text { during } \\
\text { Hepatitis B } \\
\text { injection }\end{array}$ \\
\hline
\end{tabular}




\begin{tabular}{|c|c|c|c|c|c|c|c|c|c|}
\hline 2. & $\begin{array}{l}\text { Razek, El-Dein, Jordan, } \\
2009 \\
\text { [Funding Source: None] }\end{array}$ & $\begin{array}{l}\text { Quasi } \\
\text { experiment: } \\
\text { Counter } \\
\text { balanced } \\
\text { (cross-over) }\end{array}$ & $\begin{array}{l}\text { Infants either breastfed or } \\
\text { not; } 64.2 \% \text { boys; } 1 \text { to } 12 \\
\text { months of age }\end{array}$ & $\begin{array}{l}120 ; 120 \\
120\end{array}$ & $\begin{array}{l}\text { 1) Pain score } \\
\text { measured } \\
\text { using Facial } \\
\text { Pain Rating } \\
\text { Scale before, } \\
\text { during and } \\
\text { after procedure } \\
\text { 2) Duration of } \\
\text { crying } \\
\text { 3) Heart rates }\end{array}$ & $\begin{array}{l}\text { 1) Pain } \\
\text { rating scale } \\
\text { 2) Crying } \\
\text { time } \\
\text { 3) Heart rate }\end{array}$ & 75 & $\begin{array}{l}\text { 1) Significant difference in } \\
\text { Facial Pain Rating Scale } \\
\text { between control and } \\
\text { experimental group } \\
\text { ( }<<0.05 \text { ) } \\
\text { 2) Significant difference in } \\
\text { mean of Duration of } \\
\text { Crying between control } \\
148.66 \mathrm{sec} \text { (SD13.96) and } \\
\text { experimental groups } \\
125.33 \mathrm{sec} \text { (SD12.18). } \\
\text { (p<0.005) } \\
\text { 3) Not differ significantly } \\
\text { in mean of heart rate } \\
\text { elevation between control } \\
\text { group (before procedure } \\
\text { 125.22bpm SD 29.15, after } \\
\text { procedure } 162.25 \mathrm{bpm} \text { SD } \\
\text { 40.22) and experimental } \\
\text { group (before procedure } \\
128.59 \mathrm{bpm} \text { SD 15.45, after } \\
\text { procedure } 149.210 \mathrm{bpm} \mathrm{SD} \\
\text { 20.510). p before } \\
\text { procedure = } 1.330, \mathrm{p} \text { after } \\
\text { procedure=none }\end{array}$ & $\begin{array}{l}\text { Breastfeeding } \\
\text { and skin to } \\
\text { skin contact } \\
\text { significantly } \\
\text { reduced the } \\
\text { pain in infants } \\
\text { receiving } \\
\text { immunization. } \\
\text { Pain Score } \\
\text { also showed } \\
\text { lesser in } \\
\text { breastfeeding } \\
\text { group. }\end{array}$ \\
\hline 3. & $\begin{array}{l}\text { Efe, Ozer, Turkey, } 2007 \\
\text { [Funding Source: Akdeniz } \\
\text { University Scientific } \\
\text { Research Project Unit] }\end{array}$ & $\begin{array}{l}\text { True } \\
\text { experiment: } \\
\text { Placebo } \\
\text { controlled } \\
\text { trial }\end{array}$ & $\begin{array}{l}\text { Healthy infants receiving } \\
2^{\text {nd }}, 3^{\text {rd }} \text { or } 4^{\text {th }} \text { immunization } \\
\text { of IM DTP**** either } \\
\text { breastfed before, during } \\
\text { and after injection or given } \\
\text { not breastfed; } 56.1 \% \text { boys; } \\
3.08 \pm 1.32 \text { months } \\
\text { control, } 2.79 \pm 1.13 \\
\text { months breastfed }\end{array}$ & $66 ; 66 ; 66$ & $\begin{array}{l}\text { 1) Length of } \\
\text { crying } \\
\text { 2) Heart rate } \\
\text { 3) Oxygen } \\
\text { saturation } \\
\text { levels }\end{array}$ & $\begin{array}{l}\text { 1) Crying } \\
\text { time } \\
\text { 2) } \\
\text { Behavioural } \\
\text { changes }\end{array}$ & 83 & $\begin{array}{l}\text { 1) Significant difference in } \\
\text { mean of Crying duration } \\
\text { between control } 76.24 \mathrm{sec} \\
\text { (SD49.61) and } \\
\text { experimental } 35.85 \mathrm{sec} \\
\text { (SD40.11). } \mathrm{p}=0.001 \\
\\
\text { 2) Not differ significantly } \\
\text { in mean of heart rate } \\
\text { elevation between control } \\
\text { group (during procedure } \\
\text { 129.58bpm SD 38.32, after } \\
\text { procedure146.36bpm SD }\end{array}$ & $\begin{array}{l}\text { Breastfeeding, } \\
\text { maternal } \\
\text { holding, and } \\
\text { skin to skin } \\
\text { contact } \\
\text { significantly } \\
\text { reduced crying } \\
\text { time in infants } \\
\text { receiving } \\
\text { immunization } \\
\text { injection for } \\
\text { DTP }\end{array}$ \\
\hline
\end{tabular}


Table 3: Summary of Relevant Research on Effectiveness of Prophylactic Antipyretic Used as an Intervention to Decrease Fever in Infants and its Safety Issue

\begin{tabular}{|c|c|c|c|c|c|c|c|c|c|}
\hline No. & $\begin{array}{c}\text { Author; country; year of } \\
\text { publication }\end{array}$ & $\begin{array}{c}\text { Research } \\
\text { design }\end{array}$ & $\begin{array}{c}\text { Study population; } \\
\text { care recipient } \% \text { boys; } \\
\text { care recipient age } \\
\text { mean (SD) }\end{array}$ & $\begin{array}{l}\text { Sample size: } \\
\text { baseline; } \\
\text { follow-up }\end{array}$ & $\begin{array}{l}\text { Exposure } \\
\text { measure }\end{array}$ & $\begin{array}{l}\text { Outcome } \\
\text { measure }\end{array}$ & $\begin{array}{l}\text { Quality } \\
\text { score }\end{array}$ & Statistical results & Conclusion \\
\hline 1. & $\begin{array}{l}\text { Rose, Juergens, Schmoele- } \\
\text { Thoma, Gruber, Baker; } \\
\text { Germany; } 2013 \\
\text { [Funding Source: Pfizer } \\
\text { Inc.] }\end{array}$ & $\begin{array}{c}\text { True } \\
\text { experiment: } \\
\text { Placebo } \\
\text { controlled trial }\end{array}$ & $\begin{array}{l}\text { Healthy infants who } \\
\text { received } 3 \text { dose infant } \\
\text { series of PCV-7 and } \\
\text { DTPa-HBV-IPV/Hib } \\
\text { plus a toddler dose } \\
\text { either received } \\
\text { prophylactic } \\
\text { Paracetamol at } \\
\text { vaccination and at } \\
\text { 6to9hour interval } \\
\text { thereafter or a control } \\
\text { group that received no } \\
\text { Paracetamol; 51.5\% } \\
\text { boys; } 2.4 \text { to } 11.7 \text { months }\end{array}$ & $301 ; 286 ; 245$ & $\begin{array}{l}\text { 1) Incidence of } \\
\text { fever } \\
\text { 2) Baby } \\
\text { Conditions } \\
\text { 3) Crying }\end{array}$ & $\begin{array}{c}\text { 1) Fever } \\
\text { 2) } \\
\text { Drowsiness } \\
\text { 3) } \\
\text { Decreased } \\
\text { appetite } \\
\text { 4) } \\
\text { Decreased } \\
\text { activity } \\
\text { 5) Persistent } \\
\text { inconsolable } \\
\text { crying }\end{array}$ & 83 & $\begin{array}{l}\text { 1) Significant difference } \\
\text { in temperature } \geq 38^{\circ} \mathrm{C} \text { to } \\
\leq 39^{\circ} \mathrm{C} \text { of control } 35.8 \% \\
\text { and experimental } 9.3 \% \\
\text { groups: } \rightarrow \text { after dose } 1 \\
\text { (p }<0.001 \text { ) } \\
\text { 2) Significant difference } \\
\text { in temperature } \geq 38^{\circ} \mathrm{C} \text { to } \\
\leq 39^{\circ} \mathrm{C} \text { of control } 43.7 \% \\
\text { and experimental } 19.7 \% \\
\text { groups: } \rightarrow \text { after dose } 2 \\
\text { (p=0.000) } \\
\text { 3) Significant difference } \\
\text { in temperature } \geq 38^{\circ} \mathrm{C} \text { to } \\
\leq 39^{\circ} \mathrm{C} \text { of control } 45.6 \% \\
\text { and experimental } 19.3 \% \\
\text { groups: } \rightarrow \text { after dose } 3 \\
\text { (p=0.000) } \\
\text { 4) Not significant } \\
\text { difference in temperature } \\
\geq 38^{\circ} \mathrm{C} \text { to } \leq 39^{\circ} \mathrm{C} \text { of } \\
\text { control } 60 \% \text { and } \\
\text { experimental } 51.5 \% \\
\text { groups: } \rightarrow \text { after toddler } \\
\text { dose (p=0.221) }\end{array}$ & $\begin{array}{l}\text { 1) PCM } \\
\text { reduced } \\
\text { incidence of } \\
\text { fever } \geq 38 \mathrm{C} \text {, } \\
\text { reduction } \\
\text { significant in } \\
\text { infants but not } \\
\text { in toddler } \\
\text { 2) Fever >39C } \\
\text { was rare } \\
\text { during infant } \\
\text { series, thus too } \\
\text { few cases for } \\
\text { assessment } \\
\text { 3) PCM } \\
\text { reduced } \\
\text { incidence of } \\
\text { drowsiness, } \\
\text { reduction } \\
\text { significant in } \\
\text { infants after } \\
\text { dose } 1 \text { but not } \\
\text { in dose } 2 \text { and } 3 \\
\text { also in toddler } \\
\text { 4) PCM } \\
\text { reduced } \\
\text { incidence of }\end{array}$ \\
\hline
\end{tabular}




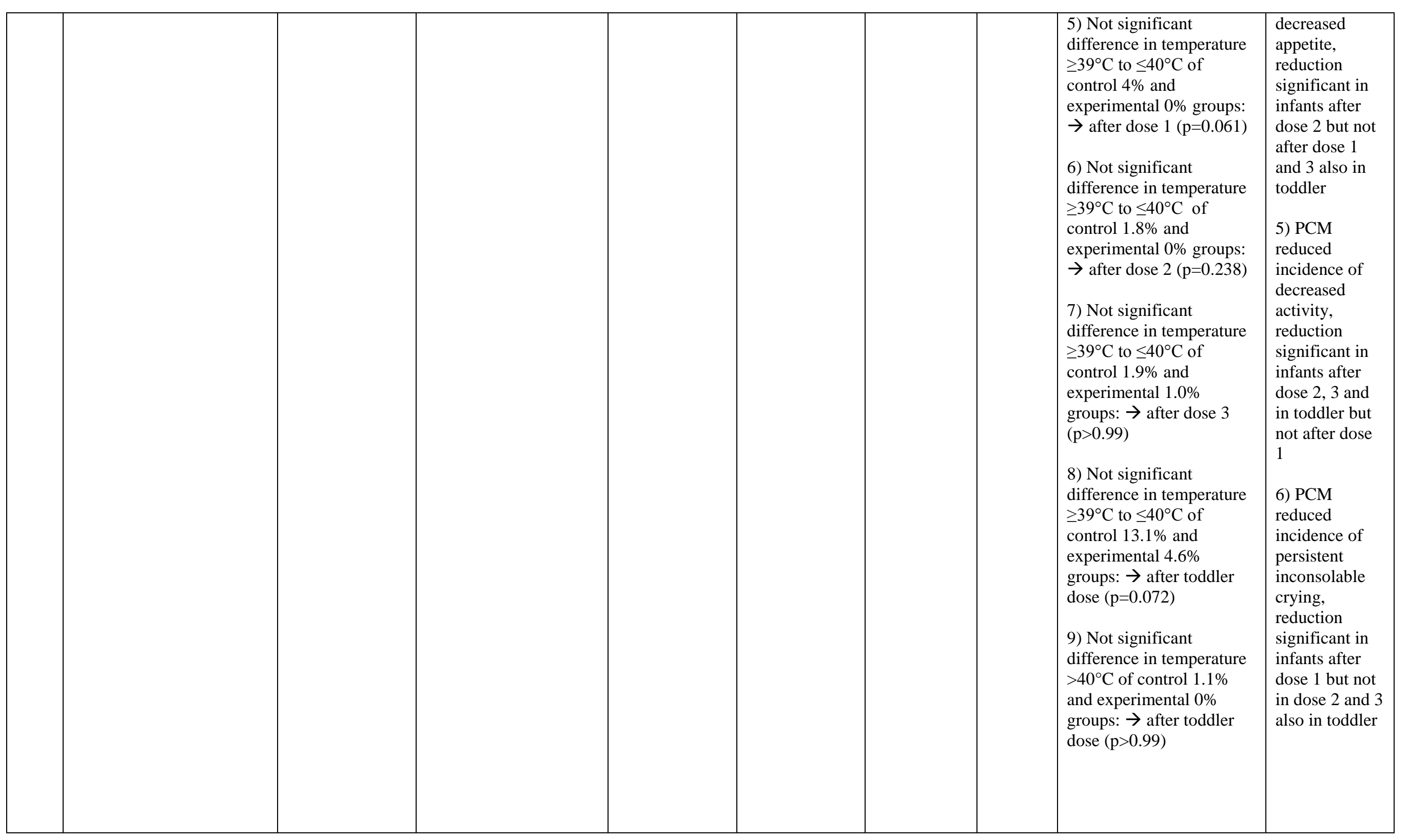




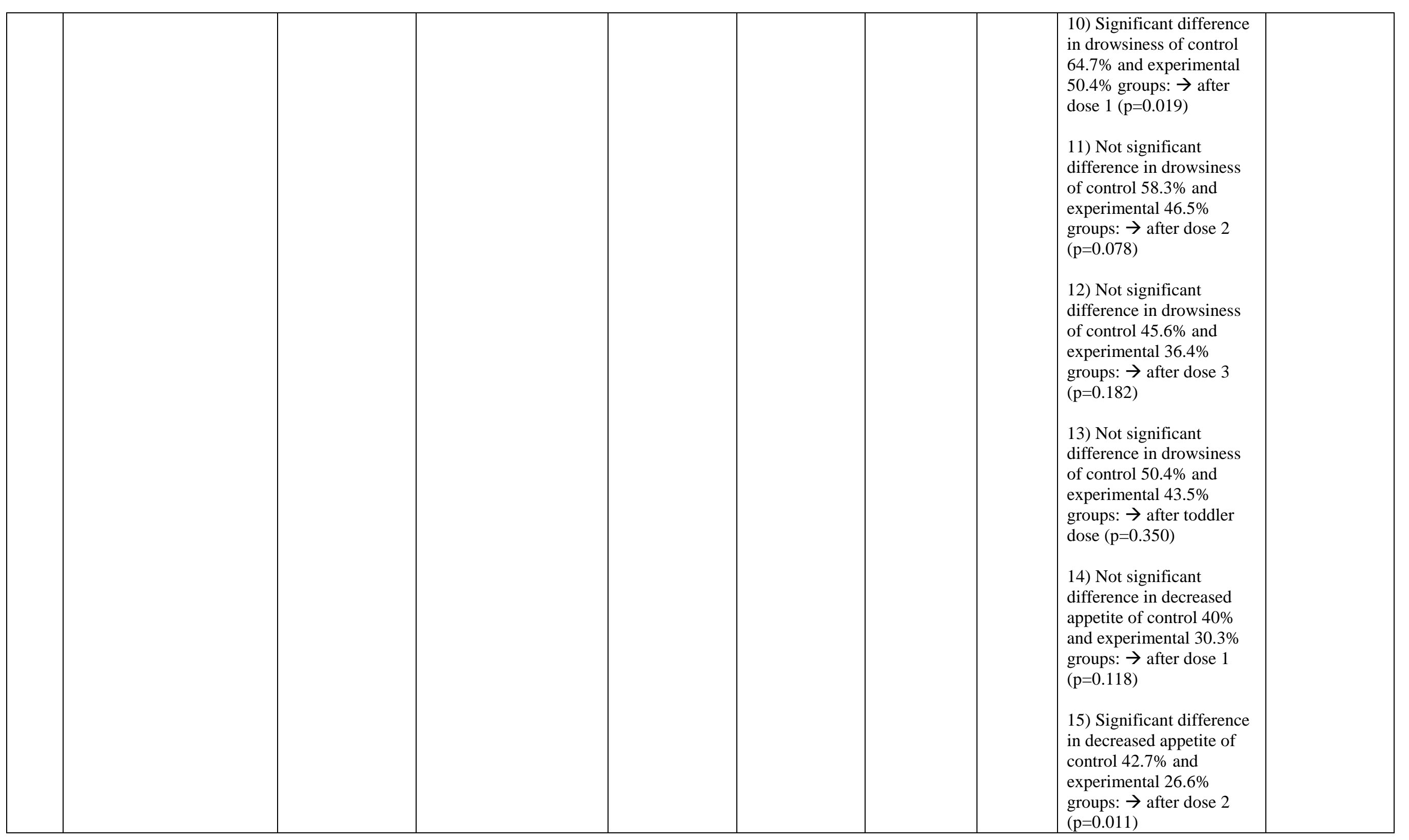




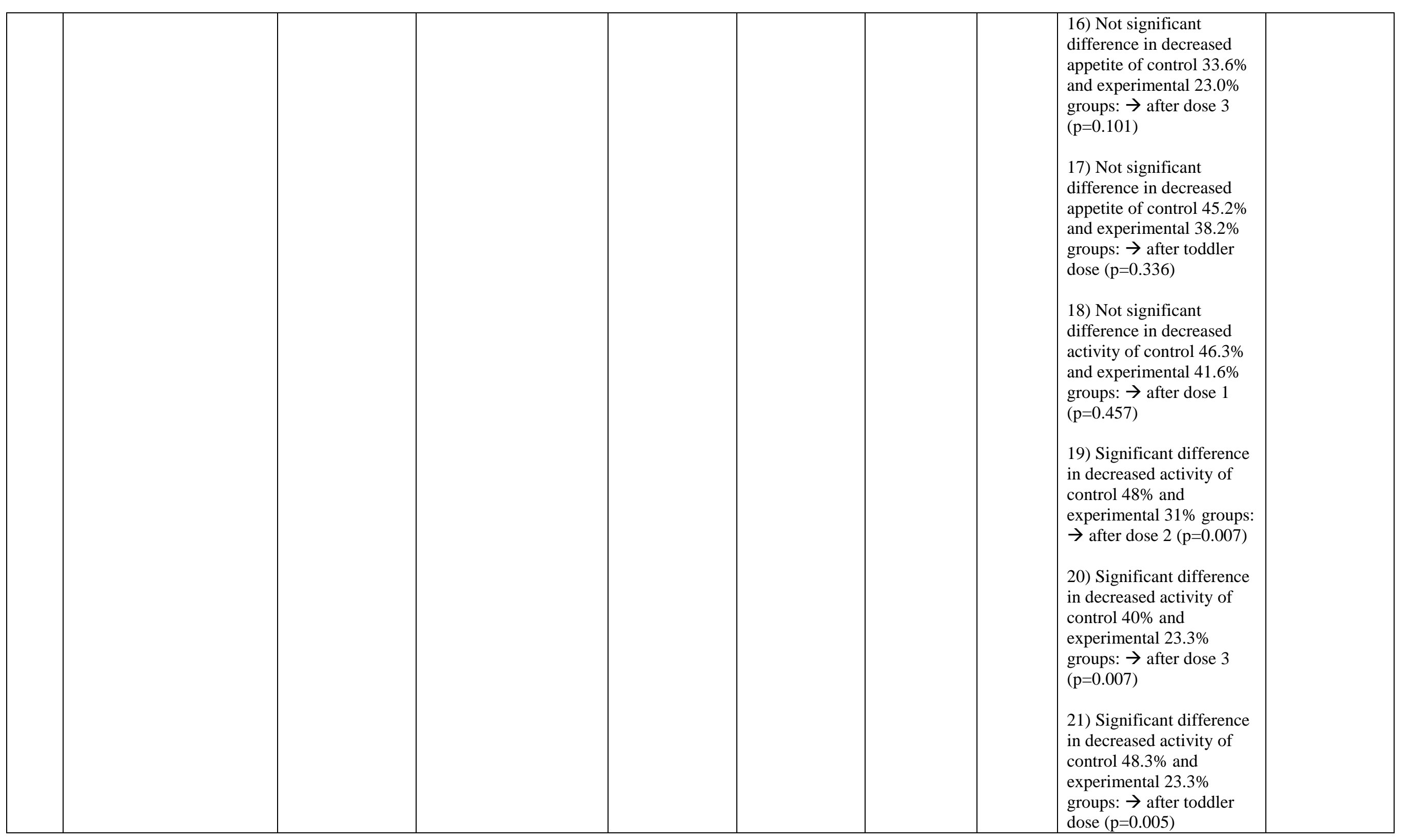




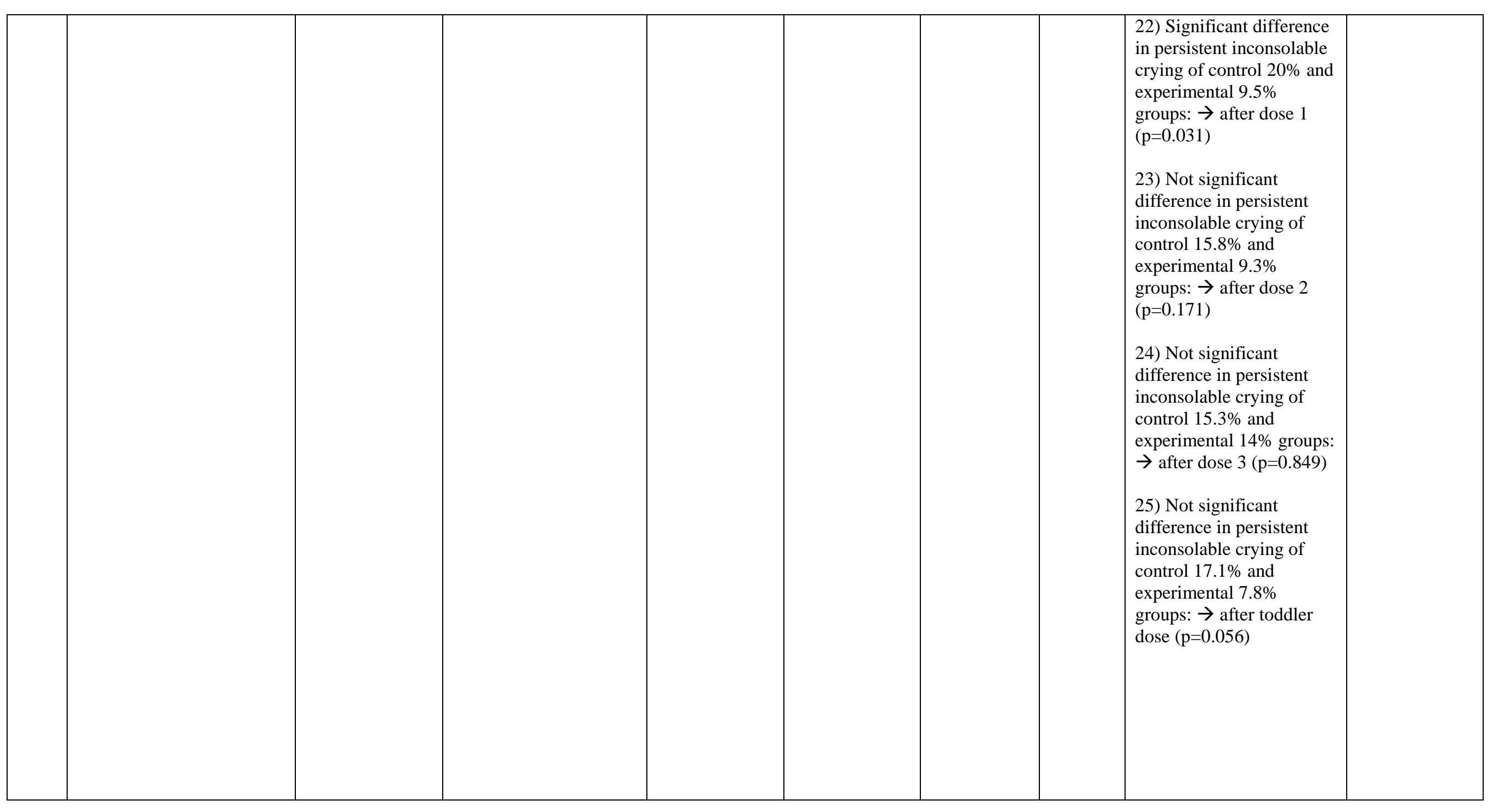




\begin{tabular}{|c|c|c|c|c|c|c|c|c|c|}
\hline 2. & $\begin{array}{l}\text { Jackson, Peterson, Dunn, } \\
\text { Hambidge, Dunstan, } \\
\text { Starkovich, Yu, Benoit, } \\
\text { Dominguez-Islas, Carste, } \\
\text { Benson, Nelson; Czech } \\
\text { Republic; 2011 } \\
\\
\text { [Funding Source: Centre } \\
\text { for Disease Control and } \\
\text { Preventive (CDC) through } \\
\text { America's Health } \\
\text { Insurance Plans] }\end{array}$ & $\begin{array}{c}\text { True } \\
\text { experiment: } \\
\text { Placebo } \\
\text { controlled trial }\end{array}$ & $\begin{array}{l}\text { Children received up to } \\
5 \mathrm{PCM} \text { doses }(10- \\
15 \mathrm{mg} / \mathrm{kg} \text { ) or placebo } \\
\text { following routine } \\
\text { vaccinations; } 51 \% \\
\text { boys; } 31 \text { weeks to } 69 \\
\text { weeks }\end{array}$ & $374 ; 352 ; 234$ & $\begin{array}{l}\text { 1) Rectal } \\
\text { temperature } \\
\text { 2) Baby } \\
\text { condition }\end{array}$ & $\begin{array}{l}\text { 1) Fever } \\
\text { 2) Fussiness } \\
\text { (more than } \\
\text { much more } \\
\text { than usual } \\
\text { and much } \\
\text { more than } \\
\text { usual) }\end{array}$ & 83 & $\begin{array}{l}\text { 1) Not significant } \\
\text { difference in rectal } \\
\text { temperature } \geq 38^{\circ} \mathrm{C} \\
\text { between the control } 22 \% \\
\text { and experimental groups } \\
14 \% \text { ( } \mathrm{p}=0.053 \text { ) } \\
\text { 2) Not significant } \\
\text { difference in rectal } \\
\text { temperature } \geq 39^{\circ} \mathrm{C} \\
\text { between the control } 2 \% \\
\text { and experimental groups } \\
0 \% \text { (p=0.08) } \\
\text { 3) Significant difference } \\
\text { in fussiness (more than } \\
\text { much more than usual) } \\
\text { between the control } 62 \% \\
\text { and experimental groups } \\
58 \% \text { ( }=0.045 \text { ) } \\
\text { 4) Significant difference } \\
\text { in fussiness (much more } \\
\text { than usual) between the } \\
\text { control } 24 \% \text { and } \\
\text { experimental groups } 10 \% \\
\text { ( } \mathrm{p}=0.001 \text { ) }\end{array}$ & $\begin{array}{l}\text { Acetaminophe } \\
\mathrm{n} \text { may reduce } \\
\text { risk of post- } \\
\text { vaccination } \\
\text { fussiness but } \\
\text { not reduce } \\
\text { fever }\end{array}$ \\
\hline
\end{tabular}




\begin{tabular}{|c|c|c|c|c|c|c|c|c|c|}
\hline 3. & $\begin{array}{l}\text { Prymula, Siegrist, Chlibek, } \\
\text { Zemlickova, Vackova, } \\
\text { Smetana, Lommel, } \\
\text { Kaliskova, Borys, } \\
\text { Schuerman; Czech } \\
\text { Republic; } 2009 \\
\\
\text { [Funding Source: GSK } \\
\text { Biologicals] }\end{array}$ & $\begin{array}{c}\text { True } \\
\text { experiment: } \\
\text { Placebo } \\
\text { controlled trial }\end{array}$ & $\begin{array}{l}\text { Children received } 3 \\
\text { prophylactic PCM } \\
\text { doses every } 6 \text { to } \\
\text { 8hourly in first } 24 \\
\text { hours, or no } \\
\text { prophylactic PCM after } \\
\text { each vaccination with } \\
\text { PHiD-CV co- } \\
\text { administered with } \\
\text { DTPa-HBV-IPV/Hib } \\
\text { and oral human } \\
\text { rotavirus vaccines; } 51 \% \\
\text { boys; mean aged at } \\
\text { time of } 1^{\text {st }} \text { dose was } \\
12.3 \text { weeks (SD 2.13). }\end{array}$ & $459 ; 459 ; 414$ & $\begin{array}{l}\text { 1) Rectal } \\
\text { temperature } \\
>39.5 \mathrm{C} \text { after } \\
\text { primary and } \\
\text { after booster } \\
\text { 2) Percentage } \\
\text { of child with } \\
\text { temperature } \\
\geq 38 \mathrm{C} \text { after at } \\
\text { least } 1 \text { dose of } \\
\text { prophylactic } \\
\text { PCM after } \\
\text { primary and } \\
\text { after booster } \\
\text { 3) Antibody } \\
\text { GMC*** after } \\
\text { primary and } \\
\text { after boosting }\end{array}$ & $\begin{array}{l}\text { 1) Fever } \\
\text { 2) Antibody } \\
\text { GMC } * * *\end{array}$ & 88 & $\begin{array}{l}\text { 1) Rectal temperature } \\
>39.5 \mathrm{C} \text { was uncommon in } \\
\text { both groups } \\
\rightarrow \text { after primary: } 1 / 226 \\
\text { participants (<1\%) in } \\
\text { prophylactic PCM group } \\
\text { vs } 3 / 233 \text { (1\%) in no } \\
\text { prophylactic group } \\
\rightarrow \text { after booster: } 3 / 178 \\
\text { (2\%) vs } 2 / 172 \text { (1\%) } \\
\text { 2) Percentage of child } \\
\text { with temperature } \geq 38 \mathrm{C} \\
\text { after at least } 1 \text { dose of } \\
\text { prophylactic PCM was } \\
\text { significantly lower } \\
\rightarrow \text { after primary: } 154 / 233 \\
\text { (66\%) and } \\
\rightarrow \text { after booster: } 64 / 178 \\
\text { (36\%) } \\
\text { in prophylactic PCM } \\
\text { group than in no } \\
\text { prophylactic PCM group } \\
\rightarrow \text { after primary: } 154 / 233 \\
\text { (66\%) } \\
\rightarrow \text { after booster: } 100 / 172 \\
\text { (58\%) } \\
\text { 3) Antibody GMC*** } \\
\text { were significantly lower } \\
\text { in prophylactic PCM } \\
\text { group than in no } \\
\text { prophylactic PCM group } \\
\text { after primary vaccination } \\
\text { for all ten pneumococcal } \\
\text { vaccine serotypes, protein } \\
\text { D, antipolyribosyl-ribitol } \\
\text { phosphate, antidiphteria, } \\
\text { antitetanus, and } \\
\text { antipertactin. } \\
\end{array}$ & $\begin{array}{l}\text { Prophylactic } \\
\text { administration } \\
\text { of antipyretic } \\
\text { drugs at time } \\
\text { of vaccination } \\
\text { should not } \\
\text { routinely } \\
\text { recommended } \\
\text { although } \\
\text { febrile } \\
\text { reactions } \\
\text { significantly } \\
\text { decreased } \\
\text { since antibody } \\
\text { responses to } \\
\text { several } \\
\text { antigens were } \\
\text { reduced } \\
\text { significantly }\end{array}$ \\
\hline
\end{tabular}




\begin{tabular}{|c|c|c|c|c|c|c|c|c|c|}
\hline 4. & $\begin{array}{l}\text { Uhari, Hietala, Viljanen; } \\
\text { Finland; } 1988 \\
\text { [Funding Source: None] }\end{array}$ & $\begin{array}{c}\text { True } \\
\text { experiment: } \\
\text { Placebo } \\
\text { controlled trial }\end{array}$ & $\begin{array}{c}\text { Healthy infants } \\
\text { vaccinated with DTP or } \\
\text { DTP-inactivated polio } \\
\text { vaccine receive placebo } \\
\text { or 75mg PCM } 4 \text { hours } \\
\text { after vaccination; not } \\
\text { mentioned; 5months }\end{array}$ & $295 ; 263 ; 263$ & $\begin{array}{l}\text { 1) } \\
\text { Temperature } \\
\text { in the evening } \\
\text { and the next } \\
\text { morning } \\
\text { 3) Percentages } \\
\text { of temperature } \\
\text { with no fever } \\
\text { and fever in } \\
\text { the evening } \\
\text { and the next } \\
\text { morning } \\
\text { 4) Levels of } \\
\text { IgG antibodies } \\
\text { (for Diphteria } \\
\text { toxoid, } \\
\text { Tetanus } \\
\text { toxoid, } \\
\text { Pertusis } \\
\text { bacteria) } \\
\text { 4) Frequency } \\
\text { of fever during } \\
\text { 24hour after } \\
\text { DTP } \\
\text { vaccination }\end{array}$ & $\begin{array}{l}\text { 1) Fever } \\
\text { 2) Antibody } \\
\text { titres }\end{array}$ & 65 & $\begin{array}{l}\text { 1) Not significant } \\
\text { difference in mean of } \\
\text { temperature in the } \\
\text { evening between the } \\
\text { control } 37.6^{\circ} \mathrm{C} \text { (SD0.49) } \\
\text { and experimental groups } \\
37.6^{\circ} \mathrm{C}(0.65) \text {. } 95 \% \\
\text { confidence limits of the } \\
\text { difference }-0.1-0.1 \\
\text { 2) Not significant } \\
\text { difference in mean of } \\
\text { temperature in the next } \\
\text { morning between the } \\
\text { control } 37.6^{\circ} \mathrm{C} \text { (SD0.53) } \\
\text { and experimental groups } \\
37.6^{\circ} \mathrm{C}(0.53) .95 \% \\
\text { confidence limits of the } \\
\text { difference -0.1-0.1 } \\
\text { 3) Not significant } \\
\text { difference in mean } \\
\text { percentages of } \\
\text { temperature with no fever } \\
\text { in the evening between } \\
\text { the control 36.5\% and } \\
\text { experimental groups } 37 \% \\
\text { 4) Not significant } \\
\text { difference in mean } \\
\text { percentages of } \\
\text { temperature with fever in } \\
\text { the evening between the } \\
\text { control } 6.75 \% \text { and } \\
\text { experimental groups } \\
6.75 \% \\
5 \text { ) Not significant } \\
\text { difference in mean } \\
\text { percentages of }\end{array}$ & $\begin{array}{l}\text { Acetaminophe } \\
\mathrm{n} \text { in a single } \\
\text { dose schedule } \\
\text { is ineffective } \\
\text { in decreasing } \\
\text { post- } \\
\text { vaccination } \\
\text { fever and } \\
\text { antibody } \\
\text { response also } \\
\text { showed not } \\
\text { significant } \\
\text { differ in } \\
\text { control and } \\
\text { experimental } \\
\text { group }\end{array}$ \\
\hline
\end{tabular}




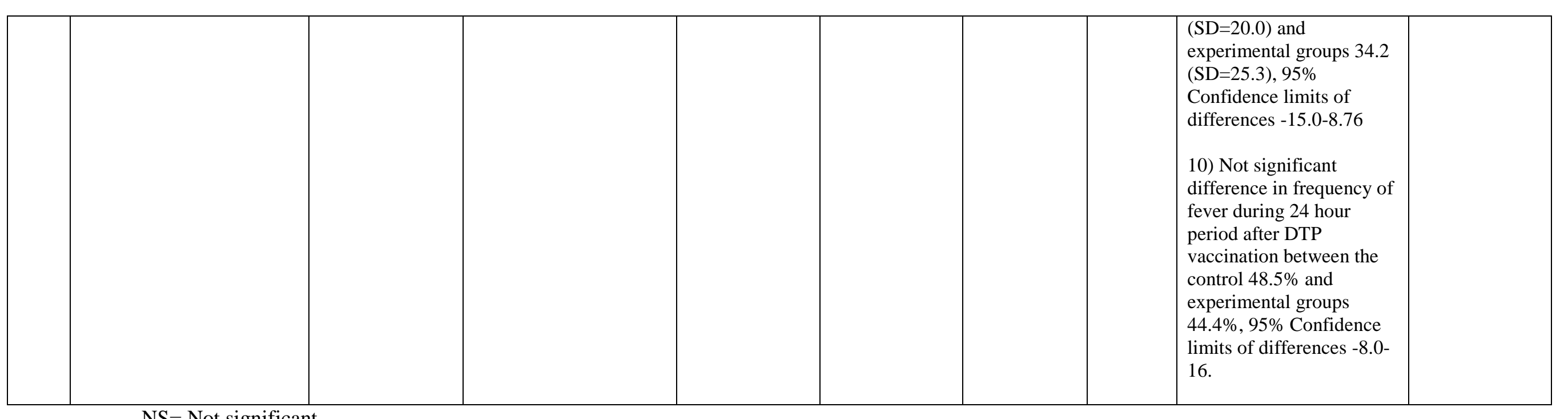

$\mathrm{NS}=$ Not significant

DTP=Diphteria, Tetanus and Pertusis 